\title{
PRODUK ORIGINAL EQUIPMENT MANUFACTURER (OEM) BERDASARKAN SUDUT PANDANG KONSUMEN
}

\author{
HERMANTO DAN YUNITA BUDI RAHAYU SILINTOWE \\ Fakultas Ekonomika dan Bisnis, Universitas Kristen Satya Wacana, Salatiga
}

One of the company's efforts to reduce operating costs, the speed of product delivery time, and improve product quality is by producing OEM products. OEM products are expected to play a critical role in the market and control the range of competitive values of product sales. The purpose of this research is to explain consumer perception of price, quality, and packaging of Original Equipment Manufacturer (OEM) product printer spare parts in Karunia Toner store. Consumer perception data using primary data obtained by using in-depth interview technique. As research subjects are consumers, who have purchased an OEM product at the Karunia Toner store. As the factors of perception include price, quality, and product packaging. Data analysis using qualitative descriptive analysis technique with data collection stage, data reduction, conclusion drawing and display data. The results show that consumer perception when viewed from the quality, OEM products have less good quality; from the price aspect, OEM products have low prices, resulting in a negative perception for consumers; while from packaging, OEM product packaging is also considered less attractive, the size is too small and the packaging image is simple, and the quality of packaging is also less good. Consumer perceptions of OEM printer spare part products are not good enough in the eyes of consumers.

Keywords: Original Equipment Manufacturer, Consumer Perception, Quality Perception, Price Perception, Packaging Perception 


\section{PENDAHULUAN}

Seiring dengan berkembangnya jaman, setiap konsumen memiliki persepsi yang berbeda-beda terhadap suatu produk, karena konsumen berasal dari berbagai segmen yang tentu memiliki sikap dan pola pikir berbeda dalam menilai suatu objek. Perbedaan kebutuhan dan keinginan konsumen menimbulkan perilaku pembelian yang unik. Perusahaan yang ingin produknya dikenal dan menarik minat konsumen, perusahaan perlu mengetahui dan memahami perilaku konsumen terhadap produk yang nantinya akan ditawarkan. Dalam perusahaan tindakan untuk mencapai kesuksesan harus menjalankan pemasaran yang baik, agar perusahaan mendapatkan keuntungan yang lebih besar. Aktivitas pemasaran memiliki tujuan untuk dapat mempengaruhi konsumen agar membeli barang dan jasa yang ditawarkan oleh perusahaan.

Bagi seorang konsumen yang membeli suatu produk, pertama-tama mereka harus mengenali produk tersebut. Pengenalan produk dapat diketahui melalui merek maupun iklan produk. Merek adalah tanda, simbol atau rancangan atau kombinasi dari semua ini yang dimaksudkan untuk mengidentifikasi produk atau jasa penjual atau kelompok penjual dan untuk mendiferensiasikannya dari barang atau jasa pesaing (Kotler \& Keller, 2012). Selain membedakan satu produk dengan produk yang lain, merek juga memberi manfaat bagi konsumen diantaranya membantu mengidentifikasi manfaat yang ditawarkan dan kualitas produk. Konsumen lebih mempercayai produk dengan merek tertentu dari pada produk tanpa merek meskipun manfaat yang ditawarkan sama.

Setiap konsumen dalam mengkonsumsi suatu produk bisa dinilai dari kualitas produk, apabila kualitas produknya bagus maka akan tercipta rasa kepuasan konsumen terhadap produk tersebut. Produk original adalah produk yang merupakan barang resmi dari pihak pembuatnya. Barang ini murni diproduksi, diseleksi, distandarisasi oleh sang produsen sendiri sehingga kualitas barang benar-benar terjaga dan tidak mengecewakan para pembelinya (Basri, n.d.). Produk original akan diproduksi dalam jumlah yang terbatas, sehingga akan menimbulkan permintaan pasar yang ting- gi, apabila pihak produsen memproduksi produk original dalam jumlah yang banyak maka membutuhkan biaya oprasional yang tinggi, salah satunya biaya upah ketenagakerjaan yang cukup besar. Pihak produsen akan tetap memproduksi produk original, namun akan diproduksi ditempat yang berbeda, tindakan tersebut untuk mengurangi biaya operasional, kemudian produk yang dihasilkan tersebut dinamakan produk Original Equipment Manufacturer (OEM) (Quesada, Syamil, \& Doll, 2006).

Original Equipment Manufacturer (OEM) adalah dimana perusahaan pertama yang telah membuat komponen atau bahan baku utama untuk membuat suatu produk, kemudian komponen tersebut diolah di perusahaan baru, dan perusahaan baru menggunakan komponen atau bahan baku utama tersebut untuk membuat produk yang sama dengan produk yang di produksi oleh perusahaan sebelumnya, namun untuk yang 'pemakai brand', barang OEM tentu tidak bisa menunjukkan branded atau yang ternama sebelumnya, dan barang OEM menciptakan merek dan desain kemasan baru. Dengan adanya produk OEM perusahaan dapat mengurangi biaya operasional, kecepatan waktu pengiriman produk, meningkatakan kualitas produk, dan perusahaan dapat melihat bagimana cara supplier memainkan peranan kritis dalam mengontrol rangkaian nilai kompetitif. Performa ketepatan supplier menentukan kemampuan dari produk OEM untuk mengimplementasi perubahan teknik dan juga secara cepat menyapu habis produksi dari hasil produk baru (Quesada et al., 2006).

Original Equipment Manufacturing (OEM) merupakan suatu komponen atau sparepart pendukung dalam proses perakitan (Arifin \& Fachrodji, 2015). Salah satu komponen pendukung dalam meningkatkan industri otomotif yang penting adalah ban. Di antara berbagai merk ban yang ada di pasaran Indonesia, yang mengalami pertumbuhan penjualannya secara tajam dan termasuk produk OEM adalah ban merk Hankook. Selain produk OEM otomotif, melainkan juga ada pada produk printing yaitu sparepart printer. Perkembangan pada printer terus terjadi mulai dari Printer dot matrix hingga printer laser jet yang terus melakukan penyempurnaan produk dengan mengikuti 
perkembangan teknologi yang ada. Jenis printer laser jet merupakan jenis printer yang metode pencetakannya tinta bubuk atau yang biasa di sebut toner dengan menggunakan perangkat infra merah. Selain hasil cetak yang lebih bagus jika dibanding dengan jenis printer dot matrix maupun ink jet, printer laser jet juga memiliki kecepatan pencetakan yang tinggi dan hasil cetaknya pun juga lebih cepat dan kering (Niko, 2014) . Printer laser jet diperlukan perawatan dan pergantian komponen-komponen diantara lainya sepeti cartridge, drum, fuser, dan komponen lainnya. Pergantian komponen bertujuan untuk mendapatkan hasil cetak yang sempurna, dan komponen printer laser jet tidak hanya yang original melainkan ada yang OEM.

Karunia Toner adalah salah satu cabang toko persediaan produk OEM sparepart printer laserjet di kota Salatiga yang menyediakan beragam produk OEM untuk berbagai macam printer laser-jet. Produk di toko Karunia Toner merupakan produk yang masuk dalam kategori Shopping Product. Dimana saat konsumen membeli produk OEM di toko Karunia Toner, sering sekali membandingkan produk OEM Karunia Toner dengan produk ternama seperti produk Samsung dan HP. Berdasarkan pengamatan awal di lapangan dan hasil dari wawancara yang telah dilakukan dengan konsumen yang pernah mengunjungi toko Karunia Toner diperoleh keterangan bahwa selain memiliki kelebihan, produk OEM di toko Karunia Toner juga memiliki beberapa kekurangan yang harus diperbaiki. Hal ini sangat mempengaruhi tingkat penjualan produk OEM di toko Karunia Toner. Oleh karena itu, pihak Karunia Toner harus mengetahui dan memperbaiki segala kekurangan yang ada, untuk meningkatkan usaha toko Karunia Toner.

Penelitian sebelumnya yang dilakukan oleh Rakhman, yang menganalisis persepsi konsumen terhadap produk rokok Fit Mild Bright untuk menentukan persepsi konsumen terhadap produk rokok Fit Mild di wilayah perkotaan Kabupaten Jamber (Rakhman, 2013). Variabel yang digunakan dalam penelitian ini mutu produk, ciri produk, desain produk, sifat produk dan rangsangan produk. Hasil dari penelitian persepsi konsumen terhadap rokok merek Fit Mild Bright di wilayah perkotaan Kabupaten Jember adalah bagus. Selain penelitian Rakhman terdapat juga penelitian Wibisono yang menganalisis tentang Persepsi Konsumen Terhadap Produk Private Label Indomaret, Studi Pada Indomaret di Salatiga (Wibisono, 2014). Variabel yang digunakan dalam penelitian ini harga, kualitas, kemasan, dan nilai fungsional. Hasil dari penelitian Persepsi Konsumen Terhadap Produk Private Label Indomaret adalah bagus.

Berdasarkan uraian di atas maka masalah dalam penelitian ini adalah mengetahui persepsi konsumen terhadap produk Original Equiment Manufacturer (OEM) sparepart printer di toko Karunia Toner. Tujuan dari penelitian ini dapat memaparkan persepsi konsumen terhadap Original Equitment Manufacturer (OEM) sparepart printer di toko Karunia Toner. Adapun persepsi konsumen yang digunakan dalam penelitian ini adalah persepsi mengenai kualitas, harga dan kemasan produk. Dengan mengetahui persepsi kualitas, harga dan kemasan, pihak Karunia Toner diharapkan dapat memperbaiki segala kekurangan yang ada, untuk meningkatkan usaha Karunia Toner.

\section{TINJAUAN PUSTAKA}

\section{Persepsi Konsumen}

Persepsi adalah proses bagaimana seorang melihat, memilih, merumuskan dan menafsirkan informasi untuk menciptakan suatu gambaran yang berarti mengenai dunia. Konsumen adalah semua orang yang membeli dan mengkonsumsi barang dan jasa. Jadi persepsi konsumen adalah merupakan suatu proses seorang individu yang merupakan pembeli dan pengguna barang atau jasa, memilih, mengorganisasi dan menafsikan masukan-masukan informasi untuk mengoptimalkan gambaran yang bermakna tentang dunia (Kotler \& Keller, 2012).

Persepsi adalah cara orang memandang di dunia ini. Dari definisi yang umum ini kita dapat melihat bahwa persepsi seseorang akan berbeda dari yang lain. Cara memandang dunia sudah pasti dipengaruhi oleh sesuatu dari dalam maupun luar orang itu.Media masa dengan segala bentuknya, bisa membentuk persepsi yang serupa antar warga kelompok masyarakat tertentu; dalam hal pe- 
masaran, pengaruh iklan di media masa, kemasan produk, papan reklame, dsb., mempengaruhi persepsi seseorang terhadap sesuatu produk atau merek (Schiffman \& Kanuk, 2000).

Persepsi merupakan suatu proses yang timbul akibat adanya sensasi, dimana sensasi adalah aktivitas merasakan atau penyebab perasaan yang menggembirakan, kemudian tanggapan yang cepat dari indera penerima kita terhadap stimuli dasar seperti cahaya, warna, dan suara (Setiadi, 2008). Persepsi adalah proses bagaimana stimuli-stimuli itu diseleksi, diorganisasikan dan diinterpretasikan. Stimuli adalah setiap bentuk fisik, visual atau komunikasi verbal yang dapat memperngaruhi tanggapan individu. Kita merasakan bentuk, warna, suara, sentuhan, aroma, dan rasa dari stimuli. Perilaku kita kemudian dipengaruhi oleh persepsi-persepsi fisik ini.

\section{Persepsi Konsumen pada Kualitas Produk}

Pengertian kualitas berdasarkan pemikiran konsumen adalah total dari fitur dan karakteristik sebuah produk atau pelayanan yang menghasilkan kemampuan untuk menentukan kepuasan atau kepercayaan yang diperlukan (Kotler \& Keller, 2012). Kemudian berdasarkan pemikiran penjual, kualitas merupakan produk yang dinilai dari kebutuhan konsumen, melampaui harapan konsumen, dan mencapai kepuasan konsumen. Kualitas produk dan layanan, kepuasan konsumen dan profit prusahaan saling berhubungan satu sama yang lain. Level yang lebih tinggi dari kualitas dihasilkan dilihat dari kepuasan konsumen dimana didukung oleh harga yang lebih tinggi dan sering juga oleh harga yang lebih rendah. Dimensi kualitas produk meliputi kinerja (performance), keistimewaan tambahan (features), deandalan (reliability), kesesuaian dengan spesifikasi (conformance to specifications), daya tahan (durability), estetika (asthethic) (Kotler \& Keller, 2012).

Persepsi konsumen pada kualitas suatu produk diukur berdasarkan tiga indikator yaitu daya tahan produk, daya tahan dari kemasan produk, dan kemudahan mendapatkan produk (Sukma \& Baihagi, 2013). Hasil uji dari ke tiga indikator dapat diketahui bahwa konsumen sangat memperhatikan kualitas produk melalui informasi yang tertera dikemasan produk, dan ukuran produk yang me- narik. Selain dilihat dari informasi kemasan dan produk yang menarik, produk yang mudah ditemukan diberbagai pusat perbelanjaan menunjukan produk tersebut cukup terkenal dipasaran dan membentuk persepsi konsumen bahwa produk tersebut pasti berkualitas, sehingga menarik minat calon konsumen untuk mengkonsumsinya.

\section{Persepsi Konsumen pada Harga Produk}

Harga merupakan sejumlah uang yang dibebankan atas suatu produk atau jasa atau jumlah dari nilai yang ditukar konsumen atas manfaatmanfaat karena memiliki atau menggunakan produk atau jasa tersebut (Kotler \& Amstrong, 2001). Sedangkan menurut ahli yang lain, harga adalah jumlah uang yang dibutuhkan untuk mendapatkan sejumlah kombinasi dari barang beserta pelayanannya (Stanton \& William, 2001).

Jadi harga adalah sejumlah uang yang dibutuhkan konsumen untuk mendapatkan atau memiliki suatu barang yang memiliki manfaat serta penggunaannya. Menurut Kotler harga memiliki beberapa indikator yaitu: (1) keterjangkauan harga, (2) kesesuaian harga dengan kualitas produk, (3) daya saing harga, (4) kesesuaian harga dengan manfaat produksi, (5) harga mempengaruhi daya beli beli konsumen, (6) harga dapat mempengaruhi konsumen dalam mengambil keputusan (Kotler, 2012).

Persepsi konsumen pada harga akan produk yang dibelinya, melihat dari kelebihan produk tersebut dan membandingkan terlebih dahulu harga dari masing-masing produk (Susilo, 2007). Jika produk yang ingin dibeli mengalami kenaikan harga maka konsumen cendrung beralih ke produk yang lain. Semakin tinggi harga semakin tinggi pula kualitas produk yang dipersepsi konsumen.

\section{Persepsi Konsumen pada Kemasan Produk}

Pengemasan adalah semua aktivitas dalam mendesain dan memproduksi kemasan dari produk (Kotler, 2012). Pengemasan terdiri dalam tiga level dari material. Sebagai contoh kemasan parfum terdiri dari botol (kemasan utama) dalam kotak kemasan (kemasan kedua) dan dus (kemasan pengiriman). Pengemasan yang baik dapat membangun ekuitas merek dan mengontrol pen- 
jualan. Kemasan adalah wadah utama produk kepada pembeli yang menentukan keputusan akhir pembelian. Kemasan juga mempengaruhi pengalaman konsumen terhadap produk yang dikonsumsi. Kemasan produk yang efektif yaitu menarik perhatian konsumen, mendeskripsikan fitur produk, membuat kepercayaan konsumen, dan membuat persepsi yang baik bagi konsumen. Kemasan memiliki beberapa indikator yaitu ukuran, bentuk, bahan, warna, tulisan, dan logo (Kotler, 2012).

Persepsi konsumen mengenai kemasan produk sangatlah subjektif dan beraneka ragam (Wibisono, 2014). Konsumen mendapatkan suatu produk dilihat dari segi desain kemasan, warna kemasan, dan daya tahan kemasan.

\section{METODE PENELITIAN}

Penelitian ini akan menggunakan penelitian deskriptif yang menggambarkan atau melukiskan suatu keadaan tertentu. Di dalam penelitian ini yang akan digambarkan penulis adalah Persepsi Konsumen terhadap Produk Original Equpment Manufacturer (OEM) di toko Karunia Toner. Subyek yang akan digunakan dalam penelitian ini adalah konsumen yang pernah membeli produk OEM di toko Karunia Toner, berjumlah sepuluh orang yang sudah pernah membeli produk OEM di toko Karunia Toner. Penentuan sampling tersebut menggunakan teknik purposive sampling. Purposive sampling merupakan teknik penentuan sampel dengan pertimbangan tertentu, kemudian pengambilan sampel secara sengaja sesuai dengan persyaratan sampel yang diperlukan (Sugiyono, 2013). Penentuan sampel tersebut berdasarkan kedudukan yang dimiliki oleh responden. Kedudukan yang dijadikan kriteria dalam penentuan sampel ini adalah kedudukan konsumen Karunia Toner.

Penelitian ini menggunakan data primer. Untuk teknik memperoleh datanya menggunakan teknik in-depth interview yaitu untuk menemunkan permasalahan secara lebih terbuka, di mana pihak yang diajak wawancara diminta pendapat, dan ide-idenya (Sugiyono, 2013). In-depth interview direkam menggunakan peralatan digital audio recording. Kemudian dianalisis mengguna- kan konten dan analisis tematik untuk menggambarkan frekuensi seberapa sering objek tertentu dikarakteristikkan secara khusus (Sinaga, 2015), yang berhubungan dengan Persepsi Konsumen terhadap Produk Original Equipment Manufacturer (OEM) di toko Karunia Toner.

Teknik analisis data dalam penelitian ini akan menggunakan teknik analisa deskriptif kualitatif. Teknik analisa deskriptif kualitatif adalah proses mencari dan menyusun data yang diperoleh dari hasil wawancara, catatan lapangan, dan bahanbahan lain secara sistematis sehingga mudah dipahami dan temuannya dapat diinformasikan kepada orang lain (Sugiyono, 2013). Teknik analisis data yang digunakan meliputi 4 tahap yakni:

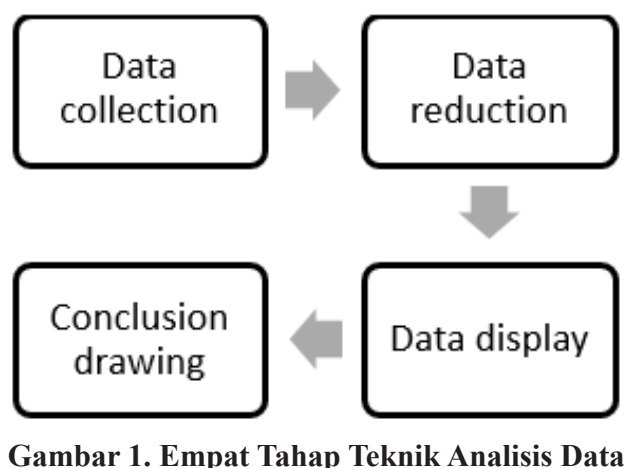

Pertama data collection memindahkan rekaman wawancara selama proses wawancara ke dalam bentuk tertulis secara rinci dan teliti. Kedua, data reduction yaitu mendeskripsikan identitas subyek, memilih hal-hal pokok, memfokuskan pada hal-hal yang penting, menentukan bentukan pola-pola perilaku yang ditunjukkan oleh masingmasing subyek selama proses wawancara. Ketiga, data display setelah data direduksi langkah selanjutnya yaitu menyajikan data dengan mengelompokkan hasil jawaban dari informan dengan tujuan agar data dapat terorganisasikan, tersusun dalam hubungan yang sama. Keempat, conclusion drawing menarik kesimpulan berdasarkan hasil jawaban dari informan.

\section{HASIL DAN PEMBAHASAN}

\section{Persepsi Konsumen pada Kualitas Produk}

Kualitas berdasarkan pemikiran konsumen adalah total dari fitur dan karateristik sebuah 
produk atau pelayanan yang menghasilkan kemampuan untuk menentukan kepuasan atau kepercayaan yang diperlukan (Kotler \& Keller, 2012). Kualitas produk berpengaruh besar untuk konsumen membeli suatu produk. Dalam penelitian ini sebagian besar responden menjadikan kualitas suatu produk sebagai faktor yang dijadikan pertimbangan dalam memilih produk.

Berdasarkan dari hasil penelitian ini 7 dari 10 informan menjadikan kualitas produk OEM sebagai faktor yang dijadikan pertimbangan dalam membeli produk OEM. Kualitas produk OEM sangat mempengaruhi konsumen untuk membeli produk OEM. Hal tersebut dikarenkan produk OEM sparepart printer masih memiliki kualitas yang belum bagus. Produk OEM dianggap sebagai produk yang memiliki kualitas rendah. 7 informan mengungkapkan bahwa produk OEM memiliki kualitas yang tidak bagus walaupun dikatakan original. Tujuh informan ini kurang percaya dan meragukan kualitas produk OEM. Pendapat ini juga didukung dalam penelitian sebelumnya oleh Wibisono, konsumen setuju bahwa produk asli dan merek terkenal dapat lebih dipercaya dan memiliki kualitas yang lebih baik (Wibisono, 2014). Berikut ini ungkapan dari informan 6 yaitu :

"Kalau dari kualitas sih ya mas, memang kurang bagus mas, produk OEM itu, banyak cacat barang ne mas, wes ga begitu percaya aku mas, kalau barang OEM itu ori dan bagus." (Informan 6)

Kualitas penilaian kinerja dan jaminan produk OEM sparepart printer masih belum memadai, hal ini masih terjadi kemacetan dalam operasional nya. Toko karunia tidak memiliki jaminan atau garansi service produk OEM dalam jangka panjang, namun hanya memiliki jaminan produk apabila tidak bisa dipakai dan bisa ditukar kembali selama 1 kali 24 jam. 7 dari 10 informan menggunakan produk OEM yang kinerja produk OEM yang tidak baik, dan kerusakan produk sebelum usianya. Berikut ungkapan dari informan 1 :

"Untuk kinerjanya diawalnya sih bagus, tapi nanti belum masa usianya dia sudah mulai troublenya seperti hasil print out sudah kurang jelas, padahal isi tonernya masih, intinya masih kurang bagus kinerjanya, mohon ditingkatkan lagi." (Informan 1)

Kelengkapan dan kesesuaian dengan spesi- fikasi produk OEM sparepart printer juga masih belum sesuai, ini dikarenakan beberapa produk OEM yang didapatkan tidak cocok, tidak sesuai, dan tidak lengkap, sehingga beberapa konsumen memperoleh barang tidak bisa digunakan, dikarenakan kurang lengkap sparepartnya. Seperti yang di ungkapkan oleh informan 9 yaitu :

"Macam-macam yang kurang mas, kadang isi tonernya, kadang bhusingnya, kadang chipnya, trus itu lho mas, yang membuat hasil print kotor dan tidak jelas, kayak magnet roll sama PCR yang dalam catridge saya beli, itu bukan buat type $85 \mathrm{~A}$, terus saya bongkar ternyata magnet roll sm PC buat type 12 A pantasan hasil e jelek, ukuran e kebesaran." (Informan 9)

Bentuk fisik, model, desain, warna dan ukuran beserta daya tahan produk OEM sparepart printer belum terpenuhi, hal ini telah diungkapkan oleh 7 dari 10 informan bahwa ukuran sparepartnya kepanjangan, kependekan dan kebesaran beserta daya tahannya kurang. 7 dari 10 yang pernah mendapatkan produk OEM yang tidak cocok ukuran bentuk fisiknya, beserta daya tahannya kurang yang seharusnya produk OEM bisa dipakai sampai 3 kali refil, namun ungkapan dari informan hanya bisa di pakai rata-rata 2 kali refil, sehingga menimbulkan hasil yang tidak memuaskan. Seperti yang diungkapkan oleh informan 1 dan 3 yaitu:

"Kalau untuk kelamaan atau usia ketahanan sparepart OEM masih kurang terkadang mas, soalnya saya pakainya 2 kali refil sudah habis, tidak bisa dipakai lagi.” (Informan 1)

"Kalau dari bentuk fisik atau ukuran kadang ada yang beda mas, atau tidak cocok, barangnya kadang kepanjangan gitu mas. Kayak magnet roller kadang kepanjangan jadi ga muat, dan opc drum buatnya itu agak gak mulus, saat dipasang ke mesin bunyi-bunyi mas." (Informan 3)

\section{Persepsi Konsumen pada Harga produk}

Harga merupakan sejumlah uang yang dibebankan atas suatu produk atau jasa atau jumlah dari nilai yang ditukar konsumen atas manfaatmanfaat karena memiliki atau menggunakan produk atau jasa tersebut (Kotler \& Amstrong, 2001). Konsumen lebih membeli produk harga yang rendah apabila ada dua produk yang sama bentuknya, walaupun berbeda merek dan ke- 
masannya (Hartanto \& Haryanto, 2012).

Berdasarkan pernyataan yang dikemukakan oleh sebagian besar informan, konsumen menjatuhkan pilihan untuk membeli produk OEM karena harganya yang lebih murah dibandingkan dengan produk jenis lainnya, namun beberapa konsumen juga mempertimbangkan harga produk OEM sparepart printer yang belum sesuai. Perselisihan harga diperkirakan mencapai 40\% dibandingkan dengan produk jenis lainya, yang membuat konsumen tertarik. Hal ini disebabkan oleh pendapatan konsumen yang pas-pasan, dan dengan ia membeli produk OEM, ia dapat menghemat pengeluarannya.

Persepsi konsumen pada harga produk OEM dilihat dari keterjangkauan harga produk OEM dikatakan murah atau terjangkau murah, namun untuk kesesuaian harga dengan kualitas dibeberapa jenis produk OEM masih dikatakan belum sesuai, hal ini telah diuji coba oleh sebagian besar konsumen, namun belum mendapatkan yang sesusai kualitasnya, seperti pemakaian sparerpart printer berjenis opc drum, seharusnya bisa digunakan sampai 3 kali refil baru diganti, namun hasilnya hanya bisa digunakan masksimal 1 sampai 2 kali refil baru ganti, sehingga membuat konsumen mempertimbangkan kesesuaian harga produk OEM jenis OPC drum. Seperti yang diungkapkan oleh informan 8 yaitu :

"Harganya belum sesuai mas, barang nya kurang bagus, kayak tadi saya bilang mas, Cuma 1 kali refil sudah ganti, padahal kan itu harusnya 3 kali." (Informan 8)

Kemudian daya saing harga produk OEM masih dikatakan murah, sehingga harga yang murah mempengaruhi konsumen untuk membeli lagi, hal ini dipengaruhi oleh pendapatan konsumen yang pas-pasan. Seperti yang diungkapkan oleh informan 5 yaitu :

"Harga produk OEM ditoko Karunia Toner itu lebih murah kalau dibandingkan produk original ternama. Mungkin selisihnya nggak terlalu jauh ya, tapi untuk saya sendiri yang masih pendapatannya yang masih pas-pasan ya produk OEM itu lumayan lah ya" (Informan 5)

Informan 5 yang merupakan seorang pekerja kantor dengan pendapatan pas-pasan mengungkapkan bahwa dengan ia membeli produk OEM, ia dapat menghemat pengeluarannya. Menurut Kotler, konsumen memilih produk tanpa merek karena dapat menghemat biaya sebesar 30\% (Kotler, 2012). Konsumen tersebut juga tidak loyal kepada toko atau ritel dan memiliki kecenderungan untuk berpindah dari toko satu ke toko yang lain dalam mencari produk yang dibutuhkan (Chakraborty, 2011).

\section{Persepsi Konsumen pada Kemasan Produk}

Persepsi konsumen mengenai kemasan produk OEM sangatlah subjektif dan beraneka ragam. Hasil in depth interview ini konsumen mempertimbangkan kemasan dalam membeli produk OEM sparepart printer. Hal ini dikarenakan produk OEM sparepart printer memiliki kemasan yang sederhana dan kurang menarik. Konsumen sedikit mempertimbangkan kemasan dikarenakan kemasannya terlalu kecil, tipis, kemudian tidak aman bagi produknya. 7 dari 10 informan mengungkapkan kemasan sparepart OEM tidak bagus, karena kemasan mudah rusak, tidak aman bagi produknya, sehingga sebagian produk yang dibeli konsumen tidak bisa digunakan. Hal ini disebabkan produk OEM memiliki kemasan yang sederhana dan kurang tebal kemudian mudah rusak. Berikut ini ungkapan oleh informan 4.

"Kemasan gampang rusak mas, terlalu tipis mungkin ya, seperti catridge yang pernah saya beli, itu drumnya tidak berfungsi, kalau bisa diganti yang lebih bagus lagi lah kemasannya." (Informan 4)

Kemasan produk OEM sparepart printer jenis catridge yaitu desain kemasan sparepart OEM masih belum bagus dan masih ada kekurangan, seperti kekurangan keterangan pemakaian dan gambar produk tidak sesuai dengan isi kemasan. Seperti ungkapan dari Informan 4, dan 9 yaitu:

"Kalau desain kemasannya aneh mas, kurang tertarik, kalau bisa cetak yang ada gambar sesuai dengan isi dalam kemasan mas. ”(Informan 4)

"Kurang keterangan pemakaian mas, jadi kita sebagai konsumen kadang kurang tau cara pemakaiannya, tapi gak papa lah sing tak butuhkan barangnya bukan kemasannya." (Informan 9)

Hasil in depth interview ini menyatakan bahwa kemasan menjadi faktor yang diperhatikan konsumen dalam membeli sebuah produk. 7 dari 
10 responden mengatakan bahwa dalam membeli suatu produk, konsumen lebih mempertimbangkan kemasan yang mempengaruhi nilai fungsional dalam suatu produk .

Dari hasil pembahasan di atas, produk OEM sparepart printer adalah produk dengan harga yang lebih terjangkau untuk kalangan dengan pendapatan yang terbatas. Hoch and Banerjee berpendapat bahwa produk tanpa merek ditujukan untuk konsumen yang berada pada segmen price sensitive (Hoch \& Banerji, 1993). Selain itu produk OEM memiliki kualitas yang tidak terlalu baik di benak konsumen. Konsumen juga berpendapat bahwa produk OEM tidak menggunakan kemasan yang menarik dan lebih menggunakan kemasan yang lebih sederhana dan simpel. Namun sebagian konsumen tidak menjadikan kemasan produk OEM sebagai salah satu faktor pertimbangan untuk membeli suatu produk. Konsumen lebih mempertimbangkan nilai fungsional produk OEM. Produk OEM juga dapat dijadikan sebagai alat pemuas kebutuhan konsumen. Dengan demikian produk OEM dapat dijadikan alternatif produk pengganti dari produk yang mahal.

\section{Persepsi Konsumen terhadap produk OEM}

Fenomena yang menarik pada saat ini yakni konsumen lebih memilih membeli produk dengan percaya akan kualitas dari produk yang sudah terkenal dibandingkan dengan produk yang belum terkenal (Hartanto \& Haryanto, 2012). Dalam penelitian yang dilakukan melibatkan 10 konsumen toko Karunia Toner sebagai narasumber, ditemukan hasil yang berbeda mengenai pembelian produk jenis OEM. Narasumber saat diberi pertanyaan mengenai persepsi produk OEM dimana, 7 dari 10 narasumber menilai produk OEM kurang bagus.

Hasil In-depth interview yang sudah dilaksanakan, 7 dari 10 informan berpendapat bahwa produk OEM dianggap memiliki kualitas yang kurang bagus., Hal tersebut dinilai dari hasil produksinya, yang kurang memuaskan. Seperti ungkapan dari informan 8 :

"Kualitasnya gak bagus mas, soalnya kurang awet, kurang puas lah mas. Dari OPC drumnya mas, pakai sekali refil mentok 2 kali refil, sudah harus ganti. Soalnya hasilnya sudah buram." (In- forman 8)

Berdasarkan ungkapan dari informan 3 ("Menurut saya harga cukup murah mas, tapi saya lebih memilih produk dengan kualitas yang bagus, walaupun mahal sedikit. (Informan 3)) yang berpersepsi pada harga akan produk, konsumen lebih memilih produk kualitas yang lebih bagus dan harga sekitar 30\% lebih mahal, karena dengan kualitas lebih bagus dan harga sedikit mahal dapat mengurangi rasa ketidakpercayaan konsumen akan produk yang dijual ditoko tersebut.

Pengemasan yang baik dapat membangun ekuitas merek dan mengontrol penjualan. Kemasan adalah wadah utama produk kepada pembeli yang menentukan keputusan akhir pembelian. Kemasan juga mempengaruhi pengalaman konsumen terhadap produk yang dikonsumsi (Kotler, 2012). Hasil in depth interview ini konsumen mempertimbangkan kemudian memperhatikan kemasan dalam membeli produk OEM sparepart printer. Hal ini sesuai dengan ungkapan informan 8 ("kardusnya tipis mas, kurang tebal. Jadi mudah rusak kayak jatuh dari meja aja udah trouble produknya"(informan 8)), pertimbangan tersebut dikarenakan produk OEM sparepart printer memiliki kemasan yang sederhana dan kurang menarik. Konsumen mempertimbangkan kemasan seperti kemasannya terlalu kecil, tipis, kemudian tidak aman bagi produknya.

\section{Keterbatasan Penelitian}

Sudut pandang konsumen terhadap produk OEM dalam penelitian ini hanya berlaku untuk produk sparepart printer dan tidak dapat digeneralisasi untuk produk OEM yang lain, misalnya: ban.

\section{KESIMPULAN}

Berdasarkan hasil pembahasan yang disampaikan sebelumnya, dapat disimpulkan bahwa persepsi konsumen terhadap produk OEM sparepart printer masih memiliki kualitas yang belum bagus. Pertama dilihat dari hasil penilaian kinerjanya produk OEM sparepart printer masih belum lancar, masih terjadi kemacetan dalam operasional, selain itu kelengkapan isi dari produknya masih ada yang kurang, sehingga beberapa kon- 
sumen memperoleh barang tidak bisa digunakan, dikarenakan kurangan lengkap sparepartnya. Toko Karunia Toner belum menerapkan garansi untuk jaminan garansi service jangka panjang pada produk OEM sparepart printer, namun Toko Karunia Touner menerapkan garansi jangka pendek setelah pembelian produk OEM sparepart printer. Keandalan produk OEM sparepart printer masih belum sesuai, hal ini dinilai dari jaminan produk tidak rusak sebelum masa kadaluwarsa ditetapkan, beberapa konsumen mendapatkan produk yang baru beli sudah tidak bisa digunakan dikarenakan sparepart tersebut tidak bisa dijalankan, dan sering mengalami permasalahan dihasil print-out, seperti tonernya tidak keluar ataupun hasilnya kotor. Kesesuaian dengan spesifikasi juga masih belum sesuai, ini dikarenakan beberapa produk OEM yang didapatkan belum cocok atau tidak sesuai ukurannya. Daya tahan produk OEM sparepart printer belum terpenuhi, hal ini telah dilakukan uji coba oleh sebagian besar konsumen, namun belum mendapatkan hasil memuaskan atau terpenuhi, sedangkan untuk bentuk fisik, model, desain, warna dan ukuran terdapat beberapa produk yang belum sesuai, hal ini dilihat dari ukuran sparepart tidak ukurannya seperti kepanjangan, kependekan dan kebesaran.

Persepsi konsumen pada harga produk, konsumen menjatuhkan pilihan untuk membeli produk OEM karena harganya yang lebih murah dan terjangkau dibandingkan dengan produk ditempat lainnya, namun beberapa konsumen juga mempertimbangkan harga produk OEM sparepart printer yang belum sesuai. Kesesuaian harga dengan kualitas produk OEM masih dikatakan belum sesuai, hal ini telah diuji coba oleh $70 \%$ konsumen, dimana belum mendapatkan barang yang sesuai kualitasnya, seperti pemakaian sparerpart printer berjenis Opc Drum bisa digunakan sampai
3 kali refil, baru diganti, namun hasilnya hanya bisa digunakan masksimal 2 kali refil baru diganti.

Persepsi konsumen pada kemasan produk, konsumen mempertimbangkan kemasan dalam membeli produk OEM sparepart printer. Hal ini dikarenakan produk OEM sparepart printer memiliki kemasan yang sederhana dan kurang menarik, tidak sesuai dengan gambaran isi produk, terlalu kecil, tipis, kemudian tidak aman bagi produknya. Konsumen telah mengalami produk tidak bisa digunakan dikarenakan jatuh dari meja posisi produk masih dalam kemasan, kemudian produk tidak pecah namun tidak bisa digunakan lagi, dan harus diperbaiki lagi, hal ini disebabkan daya tahan kemasan kurang. Selanjutnya desain kemasan tidak menarik, dan konsumen mengemukakan bahwa ini produk sparepart printer jenis catridge, seharusnya gambar kemasan itu berupa gambar catridge tapi malah gambar bunga-bunga, kemudian kurangnya tulisan cara pemakaiannya. Namun 20\% konsumen tidak begitu mempertimbangkan kemasan produk OEM.

\section{SARAN}

1. Pihak toko perlu melakukan evaluasi penetapan harga, karena harga produk OEM belum sesuai dengan kualitas produk OEM.

2. Pihak toko perlu melakukan pengajuan peningkatan kualitas produk OEM yang dianggap konsumen memiliki kualitas yang rendah. Dengan peningkatan kualitas produk OEM maka produk OEM dapat bersaing dengan produk yang lain.

3. Kemasan produk OEM perlu diperbaiki dengan desain yang lebih menarik, dan kualitas kemasan ditingkatkan agar konsumen tidak memandang rendah produk OEM. 


\section{REFERENSI}

Arifin, E., \& Fachrodji, A. (2015). Pengaruh Persepsi Kualitas Produk, Citra Merek dan Promosi Terhadap Minat Beli Konsumen Ban Achilles di Jakarta Selatan. Jurnal MIX, 5(1), 124-143.

Basri, M. A. (n.d.). Pengertian OEM Beserta Perbedaannya dengan Original dan KW. Retrieved March 3, 2018, from https://www.nesabamedia.com/pengertian-oem/

Chakraborty, S. (2011, April 22). Perceptions and Buyer Behavior Towards Private-Label Colas: An Exploratory Study to Understand the Views of the Store Managers of United Kingdom. Retrieved from https://papers.ssrn.com/sol3/papers.cfm?abstract_id=1818844

Hartanto, A., \& Haryanto, J. O. (2012). Pengaruh Display, Kepercayaan Merek, Keakraban Merek, Persepsi Harga Terhadap Intensi Pembelian dan Pembelian Tak Terencana. In Proceeding for Call Paper Pekan Ilmiah Dosen (pp. 261-282). Salatiga: FEB UKSW.

Hoch, S. J., \& Banerji, S. (1993). When Do Private Labels Succeed? Sloan Management Review, 34(4), 57-67. Retrieved from https://shop.sloanreview.mit.edu/store/when-do-private-labels-succeed

Kotler, P. (2012). Marketing Management. New Jersey: Pearson Education Limited.

Kotler, P., \& Amstrong, G. (2001). Manajemen Pemasaran: Analisis, Perencanaan, Implementasi, dan Kontrol. Jakarta: Pre Halindo.

Kotler, P., \& Keller, K. L. (2012). Marketing Management. New Jersey: Prentice Hall.

Niko. (2014). Pengertian, Kelebihan, dan Kekurangan Printer Laser Jet - Pintar Komputer. Retrieved March 3, 2018, from http://www.pintarkomputer.com/pengertian-kelebihan-dan-kekuranganprinterlaserje/

Quesada, G., Syamil, A., \& Doll, W. J. (2006). OEM New Product Development Practices: The Case of the Automotive Industry. The Journal of Supply Chain Management, 42(3), 30-40. https://doi. org/10.1111/j.1745-493X.2006.00015.x

Rakhman, H. Y. (2013). Analisis Persepsi Konsumen terhadap Produk Rokok Fit Mild Bright di Wilayah Perkotaan Kab. Jember. Universitas Jember.

Schiffman, L. G., \& Kanuk, L. L. (2000). Consumer Behavior. New Jersey: Prentice Hall.

Setiadi, N. J. (2008). Perilaku Konsumen: Konsep dan Implikasi untuk Strategi dan Penelitian Pemasaran. Jakarta: Kencana.

Sinaga, H. J. (2015). Analisis Isi Pesan Nilai Sosial dalam Iklan Pepsodent di Televisi. Universitas Sumatera Utara, Medan.

Stanton, \& William, J. (2001). Prinsip-prinsip Pemasaran (Ketujuh). Jakarta: Penerbit Erlangga.

Sugiyono. (2013). Metode Penelitian Manajemen. Bandung: Alfabeta. 
Sukma, N., \& Baihagi, A. (2013). Analisis Persepsi Konsumen Terhadap Produk Cokelat Di Kota Banda Aceh. Jurnal Agrisep, 14(2), 54-64.

Susilo, H. J. (2007). Persepsi Konsumen Terhadap Produk Toyata Avanza dan Daihatsu Xenia (Penelitan di Semarang, Salatiga dan Solo). Universitas Kristen Satya Wacana.

Wibisono, B. (2014). Persepsi Konsumen Terhadap Produk Private Label Indomaret (Studi Pada Indomaret di Salatiga). Universitas kristen Satya Wacana. 
